\title{
The Civilizing Process and International Laws Published in the Jornal do Aracaju-SE (1872)
}

\author{
Simone Silveira Amorim, Vera Maria dos Santos, Andrea Karla Ferreira Nunes, \\ Everton Gonçalves de Ávila, Ester Fraga Vilas-Bôas Carvalho do Nascimento \\ Graduation Program in Education, Tiradentes University, Aracaju, Brazil \\ Email:amorim_simone@hotmail.com,veramstos@yahoo.com.br, andreaknunes@gmail.com, everton.vila12@gmail.com, \\ ester.fraga@gmail.com
}

How to cite this paper: Amorim, S. S., dos Santos, V. M., Nunes, A. K. F., de Ávila, E. G., do Nascimento, E. F. V.-B. C. (2016). The Civilizing Process and International Laws Published in the Jornal do Aracaju-SE (1872). Creative Education, 7, 2279-2292. http://dx.doi.org/10.4236/ce.2016.715222

Received: August 23, 2016

Accepted: September 24, 2016

Published: September 27, 2016

Copyright $\odot 2016$ by authors and Scientific Research Publishing Inc. This work is licensed under the Creative Commons Attribution International License (CC BY 4.0).

http://creativecommons.org/licenses/by/4.0/

\begin{abstract}
This article aims at discussing the institutionalization of Primary Education in Sergipe demonstrating the interdependence of foreign and Brazilian laws, which were published in the newspaper Jornal do Aracaju (1872). The evidences for it can be found through ads, educational legislation, and the Provincial Assembly speeches on Primary Education in the 19th century, in Sergipe. The sources mentioned establish an interdependent relationship among state, family and government agents, mediated by laws and the press, having been analyzed under the historiographical matrix of Cultural History. The research demonstrates the fertility of the debates in the Imperial period and the plurality of educational practices and aspects that produced a school form that was implemented throughout the 19th century.
\end{abstract}

\section{Keywords}

19th Century, Newspaper Adds, Brazil, Primary Education, Brazilian Laws

\section{Introduction}

The purpose of this article is to discuss the institutionalization of Primary ${ }^{1}$ Education in Sergipe, demonstrating the interdependence of foreign and Brazilian laws which were published in the newspaper Jornal do Aracaju (1872). In support of that purpose, aspects related to the primary school in the nineteenth century are addressed as an effort to monitor the movement that conformed the education system in Western nations and consolidated a primary school form in the province of Sergipe.

Newspaper articles with laws related to Public Instruction in some European countries and the United States were found, during research conducted with the objective of ${ }^{1}$ Primary and elementary education will be used in this text in an intertwined way. 
analyzing the constitution process of Primary Education in the nineteenth century with regard to legislation and the press movement in Sergipe. It is important to mention that this research had, as its perspective, the movement of teaching configuration, analyzing the representations and experiences of the agents involved in that process in Sergipee.

Sometimes, countries like Switzerland, France and the United States were cited in the Jornal do Aracaju ${ }^{2}$ as models to be followed when considering Public Instruction. The intentions that some people had when they decided to reproduce texts about public education in the countries mentioned were considered, and it was concluded that they were to convince the people of Sergipe that the Public Instruction in the province had some of the components of international educational laws.

Given the above conclusion, this article assumes that the citations in the Jornal do Aracaju interfered with the thinking and actions of some of the citizens of Sergipe. It will be under the latter assumptions that publications in the Jornal do Aracaju will be analyzed here.

Thus, it is not possible to infer that those laws are like tools inserted into a civilizing process (Elias, 1990), which takes into account the belief that the individual needs to learn the rules of conduct as a prerequisite of the human condition and that legitimates $\mathrm{him} / \mathrm{her}$ to live in society. Once being socially civilized, civilization eventually becomes the result of a process to which people are subjected.

The chosen path induces the research to observe this theme through its legal framework, without, however, despising its relations with society, since its educational institutions correspond to its needs in a clear interdependence. These aspects can be seen through the ads and publications in newspapers of Sergipe, educational legislation, the Provincial Assembly speeches on Primary Education in the nineteenth century in Sergipe as they established an interdependent relationship among state, family and government agents, being mediated by laws and the press (Elias, 1990).

Taking the sources mentioned into consideration, it is important to recollect facts about the third generation of the Annales and have in mind that it has proposed new objects, problems and approaches when it comes to History of Education research. Therefore, the way of questioning the texts changes as it is possible to analyze not only what they say, but also the way they say something and even wonder about the silence they set. As to its materiality, newspapers are considered here as texts written on separate sheets. However, over time, they possessed different sizes, print quality, color, images, and types of paper (de Luca, 2006).

Given this change and the new understanding of sources, historians have been led to seek topics that reflect the diffusion of new values, habits, aspirations, as well as aesthetic, social and political demands of population groups that roam the cities. Through newspapers, it is possible to see the conflicts and efforts of political elites to impose their peculiar worldview and control groups considered dangerous. On their pages, they discussed, formulated and articulated future projects as well.

Thinking of newspapers as sources is to understand that they open wider possibilities

${ }^{2}$ This newspaper belonged to Manoel Luiz, Director of Public Instruction in 1872, and also served as "official newspaper". 
of deepening our understanding of the past. They are not transparent windows to a world that, through them, we see. They are collections of newspaper reports, written by professionals who supposedly have conventions to follow and communicate in a peculiar form of narrating the ways they interpreted the events (Darnton, 2010: p. 140). The role of the researcher is then to use the tools at his/her disposal to analyze the discourses that problematize a more accurate identification of the narration of the event and the event itself.

In order to reach the objective proposed, it was necessary to present and analyze the role of the press in the schooling system taking into consideration the social and international experiences in the educational field published in the Jornal do Aracaju (1872). We also depict how the examples of the United States, France and Switzerland were used by some people involved with Public Instruction in the province of Sergipe to convince the Sergipanos that the laws that had just been approved were according to what nations considered developed at that time had in their educational system. Therefore, throughout their speeches, it is possible to realize the interdependence among state, family and legislation.

\section{United States, France and Switzerland: The Role of the Press in the Schooling of Social and International Experiences in the Educational Field Published in the Jornal do Aracaju (1872)}

Researchers such as Gondra and Schueler (2008), Cury (2011), and do Nascimento (1999), among others, found that the nineteenth century was permeated by various actions in order to institutionalize and develop the instruction under the aegis of the state. Therefore, it is understood, in this research, the institutionalization of lessons in elementary education as a process that occurred throughout the western countries and rumbled, concurrently or not, in some nations through newspapers, respecting their specificities. Thus, we observed the role of the press in social education, with the spread of representations about local, national and international experiences in the educational field (Rizzini \& da Silva Araújo, 2011).

Keeping this idea in mind, in the issue of June 5, 1872 a report sent to Councilors Francisco Manoel Corrêa by Antonio P. de Carvalho Borges that was initially published in Washington, March 9, 1872. It mentioned another report that was presented by the Body responsible for education in The United States, the Bureau of Education, to the Secretary of the Interior from that country.

The purpose of Borges's report was to understand the situation of the Public Instruction and the "efforts that are made to generalize it" in the United States. He clarified that the Public Education was governed by state and not federal laws. He also mentioned there was a Superintendent of Public Instruction and a Council, actually a State Board, which had the responsibility to organize the expenditure, the inspection of schools and the examination of teachers. The Governor and the "key" employees were part of it. However, there were specificities in the States in the United States, as there was no obligatory presence of a superintendent and the Board (de Carvalho Borges, A. 
P. (1872). Ministry of Foreign Affairs (Transcription). Jornal do Aracaju, 3, n² 279, p. 4).

He described that there were rules on compulsory education and also the payment of fines by those who did not deliver instruction to school aged children, with rules for boys and girls. He wrote that, "In the state of Massachusetts it is to be fined every person who has under his direction, a child aged 8 - 14 for not sending him/her to a public school or provide them teachers. Last year, the States of Michigan, New Hampshire and Texas have adopted similar provision [...]". (de Carvalho Borges, A. P. (1872). Ministry of Foreign Affairs (Transcription). Jornal do Aracaju, 3, n² 279, p. 4). However, according to the author, the education system was still deficient in some States such as the ones in the south. He also mentioned the efforts to educate free afro-descendants, Indians and Chinese.

Borges concluded by saying he was sending some publications: History of the Common School, Report of the Board of Trustees of Public Schools of the city of Washington and School Housis. According to him, the report of Hippeau, which had already been translated and published in the Official newspaper of Rio de Janeiro the year before would help understand the importance of attention given to the "education for both sexes" (de Carvalho Borges, A. P. (1872). Ministry of Foreign Affairs (Transcription). Jornal do Aracaju, 3, n² 279, p. 4).

For him, the objective in sending the texts was for them to serve as "inspiration", and maybe the experiences of the United States and other nations of Europe be applied in Brazil so that there was an "improvement" on Public Instruction. He also suggested that "practical" people were sent to analyze what "we lack and what we can improve in the important branch of education" (de Carvalho Borges, A. P. (1872). Ministry of Foreign Affairs (Transcription). Jornal do Aracaju, 3, n² 279, p. 4).

The idea of showing what is "good" in other nations seems to be a widespread behavior and not only a strategy of Sergipe elite. Thus, what at first could be considered as being bad or of low acceptability to the public would be viewed positively because they were considered modern and meaningful experiences in "civilized" societies.

Under the heading "Public education in France" the text transcribed in the Jornal do Aracaju $^{3}$ depicted the structure of primary education in that country. It showed the division of establishments meant to form masters and mistresses (ordinary schools, ordinary school courses and practices); primary schools where children aged 7 - 13 years old (boys' schools, girls' schools and “communaes” for both sexes); the rooms of asylum, "garderies" and small schools for children under 7 years old. This way, primary education comprised:

the moral and religious instruction, reading, writing and arithmetic, the elements of the French language, the legal system of weights and measures. It can also be comprehended: applied arithmetic to practical operations; the elements of history and geography; notions of physical sciences and ordinary use of natural history;

${ }^{3}$ Although it was found in the file of the digital edition $n^{\circ} 294$, the title of the text indicates that it is actually more recent. Thus, it is part of the newspaper number 295 and not 294 proving that it was misplaced. 
elementary instruction on agriculture, industry and hygiene: surveying, leveling, linear design; singing and gymnastics (No Authorship (1872c). A Public Instruction in France-Primary Instruction (Transcription). Jornal do Aracaju, 3, n ${ }^{\circ} 294$, p. 3).

In accordance with French law each municipality had to keep at least one public school, unless two or more unites should keep a school and still had an obligation to provide free education to children of parents who, for financial reasons, could not keep their children attending classes. Yet, it could also maintain one or more entirely free schools.

In fact, there was a long historiographical tradition in France as having a private teaching purely religious, malformed and having retrograde values as for the school system, but this view hides the presence of institutions and teachers. Recent studies have open the possibility of a more vivid and consolidated perception on the action and access to these congregations and teachers. They also found out there were clashes between Protestant and Catholic institutions (Essen \& Rogers, 2003).

Another aspect about schools in France is that the amount paid for the rental of the house to run the school was 154 francs and that municipalities should provide teachers with housing in the local schools. Inspectors were supposed to rate the quality of the schools as good, sufferable, passive, mediocre and bad.

There were requirements to be a public school teacher. It was necessary to have a diploma or equivalent certificate of ability, but the ones who were adjuncts could be exempted from this requirement. The female teachers in mixed schools also needed to provide diplomas and for the religious schools and a certificate of obedience would suffice. The salaries paid to teachers ranged 400 - 900 francs, according to the time of service.

Thus, rent, furniture and the teacher's salary would be guaranteed by the municipality where the school was created. The money would come from special taxes, the money paid by each student who attended the school, donations and "legacy", and from the state grant, but only when necessary (No Authorship (1872c). A Public Instruction in France-Primary Instruction (Transcription). Jornal do Aracaju, 3, n² 294, p. 3).

Mandatory creation and maintenance of school for girls would be for municipalities with 800 or more inhabitants. Only 18,179 out of the 37,548 municipalities did not have schools for girls, possibly due to the number of inhabitants, as the text stated that this law was generally enforced, but it was known that some worked in municipalities with less than 800 people. There were still 4500 adult classes, 300 apprentice schools, 60 "Sunday" classes, 80 schools for boys who worked in the factories and 20 houses for orphans.

There was a clear intention to demonstrate the importance of the Regular Schools, as the readers of the newspaper were informed that during a period in France, these institutions had been deleted, but the experience was not positive and since March 1850, there was a law that called for the training of teachers in regular schools.

It is noticeable the intention of the political elite to convince scholars that in some 
aspects, Sergipe, despite being behind France, was on the "right" way, since the Regulation of 24 October 1872 mentioned some of those topics, such as supervision of classes, teacher training, schools for girls, evening classes for adults etc.

Moreover, the text was published after the publication of discussions in the Provincial Assembly to approve the Regulation of 24 October. Therefore, the debates led political leaders to think about the need to convince people of the importance of reforming the Public Instruction.

Still on the text on Public Instruction in France, the level of education of individuals who "attend to justice" was described. The analysis corroborated the argument that when Public Education was compulsory, the number of defendants progressively diminish. Thus, the lack of education of individuals would be one reason for the lack of "civility" in society, a fact that caused the commission of crimes or infractions (No authorship (1872d). Public Instruction in France-OVERVIEW-Primary Instruction IContinued from $n^{\circ} 296$ (Transcription). Jornal do Aracaju, 3, n 297, 2-3).

Taking into consideration what was mentioned above, it is understood that it was necessary to civilize the adult population to decrease crime and, at the same time, watch for inappropriate behavior in society so that it would not be part of future generations. Therefore, the mandatory instruction became a solution to force parents to enroll their children in a school, including using the coercive power of the state, but at the same time taking care of the civility of illiterate adults.

For de Faria Filho (1998), it is possible to relate the dimensions of the pedagogical action through legislation as educational policy because educational practices are run through a dynamic that transcends its idea as an expression and imposition of the interests of the ruling classes. In this sense, the normative text is associated with social practices, not appearing in a vacuum.

As for disciplinary punishment in France, there was the prohibition, by law, of corporal punishment. When necessary, only the moral punishment would be tolerated and would be applied aiming at "[...] evoking the feeling of duty in the heart of pupils" who could be deprived of the recreation time, for instance. Consequently they would have to perform some activities, receive a bad score, among others (No Authorship (1872e). Public Instruction in France-OVERVIEW-Primary Instruction I (Transcription Continued from Issue 299). Jornal do Aracaju, 3, n 300, p. 2).

The text on Public Education in Switzerland published in issue no. 287 of the Jornal do Aracaju in 1872 is incomplete, but it is possible to observe the influence of religion concerning school organization in Switzerland. It reported that after the creation of the country's constitution, the Jesuits were expelled. They had created some renowned educational institutions in the country, but after the expulsion, they fell in importance.

Teaching was confessional in some Swiss "cantons" and other State Schools were mixed. The inspection and monitoring were done by school committees, inspectors and by the Department of Public Instruction. The salaries of teachers varied according to the "canton" which could receive, besides their salaries in money, a "decent home", a "garden", "firewood", "land" and progressive increases of their money according to the 
time of service.

It was predicted a somewhat higher salary for teachers who possessed qualification, because there were those who had a provisional license. The salary of the female masters was lower than the one of the male masters, but their wage was also likely to increase according to the length of service in the teaching profession. In some "cantons" salaries were not set by law.

The text presented by the Brazilian Minister in Switzerland indicates that there was an administrative decentralization related to the organization of education in that country and that it was possible to identify a range of actions relating to Public Instruction (No Authorship (1872b). Education Publishes-Memory on This Matter, Presented by the Brazilian Minister in Switzerland (Transcription). Jornal do Aracaju, 3, n 287, 2-3).

All those facts mentioned so far show that topics just like mandatory schooling, punishment, teachers' salaries as well as the importance of education to the organization and civilization of a society are of great importance for the development of countries. Therefore, it was imperative to improve education in Brazil so that there would be possible for the country to develop just like the ones presented in the newspaper and one of the ways to reach that goal would be thorough the improvement in the laws that ruled public instruction in the province of Sergipe.

\section{Brazil and the Spreading of Elementary Education}

In Sergipe, Mr. Oliveira Ribeiro, as for the discussion on the Regulation of 24 October and the mandatory teaching, ardently defended it, noting the examples of the United States, France, Germany, Russia, Austria, Portugal and Denmark. He claimed that "[...] public instruction was the only refuge of our hopes, because only through it, we will break the iron barrier that separates us from civilized peoples, and only then we will occupy a place of honor [...]" (Ribeiro, O. (1872). Provincial Assembly: Speech Delivered by Mr. Oliveira Ribeiro in Session 11 of the Ongoing Year. Jornal do Aracaju, 3, $\mathrm{n}^{\circ} 263, \mathrm{p} .1$ ).

Once stated that the mandatory elementary education was a civilizing element in European nations that were on the "edge of civilization", it was mentioned that this type of education had transformed the United States of America in the representative nation of freedom, in a "center of light", having embraced it enthusiastically, already harvesting its fruits (Ribeiro, O. (1872). Provincial Assembly: Speech Delivered by Mr. Oliveira Ribeiro in Session 11 of the Ongoing Year. Jornal do Aracaju, 3, n² 263, p. 1).

The subject was approached because an amendment abolishing compulsory education had been proposed. Oliveira Ribeiro clearly showed the importance of the State action in the provision of compulsory education, as some deputies were contesting the right of this and considering this act as depriving of individual freedom and that interfered in the domestic education.

When mentioned that this same discussion was waged in France, Ribeiro reported that the individual freedom of the child would not be violated given that he/she would 
be given the "inviolable right to ignorance". Likewise, there would be no depriving of the individual freedom of parents because, however, it would not be given to them the "[...] right to perpetuate social calamities through his/her child's ignorance" (Ribeiro, O. (1872). Provincial Assembly: Speech Delivered by Mr. Oliveira Ribeiro in Session 11 of the Ongoing Year. Jornal do Aracaju, 3, n² 263, p. 1).

In Oliveira Ribeiro's speech it is possible to realize the interdependence between state, family and legislation. The State, through the imposition of compulsory education, would make parents enroll their children in school and this new generation would be responsible for the growth of the nation. Reading and writing would also provide citizens knowledge of their rights and that goal to be achieved would not be set in a restriction of individual freedom.

In Sergipe the issue of maintenance of primary schools marked the nineteenth century. Teachers constantly needed to resort to official correspondence to inform the non-payment of rents of the houses where they lived and where classes were taught.

This was the case of the teacher Bricio Cardoso that "reminded" that the City Council of Estância should take responsibility for teachers' houses according to art. 224 of Regulation of 24 October, 1870. The reminder was due to the fact that it had not yet provided the rent payment. It was sent to communicate the Council that the teacher's request should be granted (Cardosom, B. (1872). Warning. Jornal do Aracaju, 3, n 248, p. 1).

The following edition replied to the petition of teacher Bricio Cardoso, who requested $\$ 27,000$ related to the payment of the house rent in which he lived and taught during the months of October, November and December in 1871, having the payment been deferred (Provincial Government (1872a). Government of the Province: March 9, 1872. Jornal do Aracaju, 3, n² 249, p. 1).

The fact is that the City Council of Estância should pay the rents of the houses in which teachers lived and taught their classes with "[...] resulting amounts of leftovers that may come from other funds [...]". If this action was not possible, it should open credit "[...] which the legislative body will report in due course". In fact, it was necessary that, when drafting future budgets, funds were intended for the payment of such expenses. A statement to the provincial treasury was, then, made (Provincial Government (1872b). Government Expedient. Jornal do Aracaju, 3, n² 260, p. 1).

Actually, the Regulation of 24 October, 1870 forced the City Councils to afford such payments. Teachers had that right, but it was constantly disrespected. Perhaps the Councils had not been asked whether they could afford this responsibility, or had other priorities, or even did not think this kind of public action was important. The fact is that it was clear that they had not foreseen this expense and/or could not afford the rents.

During the process of review and approval of the Regulation, some proposals to change it were made, so there was a discussion about the project $\mathrm{n}^{\circ} .10$ (Public Instruction). Therefore, they addressed the articles concerning the tenure, provision of furniture and utensils, awards and distinctions from the province, the number of students 
for a teacher to be adjunct, penalties, among others (Provincial Government (1872c). Provincial Assembly: Session on April 12, 1872-Part 2 of the agenda. Jornal do Aracaju, 3, n ${ }^{\circ} 266$, p. 1).

They also discussed the articles that addressed the rent of the houses-in the capital it would be paid by the province and in other areas, by local councils. It was decided by law that the houses could be used to address the teacher and his legitimate family. The salaries and emoluments were discussed as well as possible replacements (Provincial Government (1872d). Government Expedient: 1st Part of the Agenda. Jornal do Aracaju, 3, n ${ }^{\circ} 267$, p. 3).

Given the discussions, B. Álvarez, T. de Faria, C. Lobão, Pelino M. Nobre e and M. Lobo proposed that municipal councils were exempted from the payment of rents from homes where the primary classes occur, leaving that payment to the teachers. However, they should provide the furniture "according to their limitations". The proposal was approved (Provincial Government (1872e). Provincial Assembly: Session on May 2, 1872. Jornal do Aracaju, 3, n² 275, p. 2).

Consequently, a law was published that, among other things, in Article 22, the rents of the houses where public teachers lived and worked would be paid by themselves, teachers from the capital were exempt. However, the Municipal Councils would provide the furnishings for classes "according to their limitations" (Provincial Government (1872f). Law 951 of May 8, 1872. Jornal do Aracaju, 3, n² 284, p. 1).

In Brazil, according to Miranda (2009), documentation from the State of Paraiba from the first half of the nineteenth century indicates that the practice of instructing first letters was part of the professional training of individuals who were engaged in military corporations. Joaquim José d'Oliveira, 1st Lieutenant from the Artillery Hunter Battalion, made an application to the Emperor requesting permission to attend classes in mathematics from the Military Academy.

The issue of adults who were not instructed had a singularity: sought the instruction of youth, but parents could not be forgotten by the government, for their children would arrive home, supposedly knowing how to read, count and write and parents could not help them practice what had been taught at school and hardly understand the importance of studying.

Therefore, investing in the education of adults was a necessary action, it was necessary to look for a pattern of behavior not only for future generations but also for the current one. Once again, we can observe the interdependence between state, family and government agents. Thus, the civilizing process (Elias, 1990) thought for organized nations under the form of States would reach the entire population. In other words, even though that was a specific action at a specific time, it was part of the civilizing process.

It should be mentioned that in Sergipe, this need was also present on a text published in issue 247 of the Jornal do Aracaju, 1872. The text is about the importance of Public Instruction and the "choice" of teachers with morality, to be able to teach and train disciples. It also mentioned the significant role of Antonio Candido da Cunha Leitão, the Province President, who "[...] intended to raise the province of Sergipe to the best as 
possible in the matter of education" (No Authorship (1872a). Public Instruction. Jornal do Aracaju, 3, n² 247, p. 1).

According to the text, it instituted the evening classes in the capital and elsewhere in the province. The target audience was workers who could only study at night, avoiding idleness. The publication of a speech given at the Provincial Assembly, asked the deputies not to allow these classes to end, as this would result in injury to the Sergipe society.

Care for the public instruction in the province of Sergipe, and your names will be revered by your patricians. In me you will always find effectual support for your efforts because they also covet the glory of being loved and honored by the people of Sergipe (No Authorship (1872a). Public Instruction. Jornal do Aracaju, 3, n 247, p. 1).

Several speeches were made, especially through newspapers, showing the tension between intellectuals of the nineteenth century about education in Brazil. Thus, in issue $\mathrm{n}^{\circ} 273$ of the Jornal do Aracaju a text authored by J. C. Fernandes Pinheiro on Public Instruction was reproduced.

In the first part the author mentioned that he was awaiting a report from the Minister of the Empire that would deal with several considerations regarding the subject "[...] lavish subsidies and bright ideas", based on theories and examples "[...] collected in foreign institutions [...]" (Fernandes Pinheiro, J. C. (1872). Literature, Public Instruction in Brazil II (Transcription). Jornal do Aracaju, 3, n² 273, p. 4).

He continued his text criticizing the statement of an alleged anonymous foreign writer who mentioned that not long ago-67 years-Brazil was already kingdom, almost still a colony, and had few public or private schools. "[...] In Rio de Janeiro, where there were greater numbers of them, it was only heard in the distance, in some isolated house, a noise from boys, loudly memorizing his lesson; not much more, silence about the rest" (Fernandes Pinheiro, J. C. (1872). Literature, Public Instruction in Brazil II (Transcription). Jornal do Aracaju, 3, n²73, p. 4).

Pinheiro disagreed with the statement using as source the authors Silva Lisboa, L. Goncalves dos Santos and Pizarro, saying that during the period mentioned above there was a significant development with regard to the number of schools, colleges, high schools, as well as the existence of convents and seminaries. Thus, "[...] almost impossible to find a fifty-year old man who has not attended one of these institutions" (Fernandes Pinheiro, J. C. (1872). Literature, Public Instruction in Brazil II (Transcription). Jornal do Aracaju, 3, n 273, p. 4).

For him our land was essentially literary. After Pombal, Latin lessons were disseminated, the states of Minas Gerais and Bahia were known by their Latin scholars, there was the study of humanity classes composed of Logic (or Rational and Moral Philosophy); Rhetoric and Poetics; Geometry; Greek language in Rio de Janeiro, Bahia and Pernambuco. The Humanities course entitled Brazilian students to the University of Coimbra and possessed traditional reputation there. Moreover, it was possible to acquire academic titles in Brazil that were before "begged" elsewhere. He also cited many illustrious names in Brazil at the time: "not to mention others, will suffice to cite the 
name of José da Silva Lisboa, later Viscount Cairú, [...] John Severiano Maciel da Costa (later Marquis of Queluz) [...] José Luiz de Carvalho Mello (Viscount Cachoeira) which tradition points out as principal authors of our fundamental code" (Fernandes Pinheiro, J. C. (1872). Literature, Public Instruction in Brazil II (Transcription). Jornal do Aracaju, 3, n² 273, p. 4).

He concluded by saying that, in contrast, there was the delay of Primary Education, especially by the female public. Pinheiro then suggested that the Brazilians were not severe with those who preceded them in the organization of this school, hinting that the "fruits" of the gigantic "tree of Santa Cruz", were yet to come. In other words, the tree of Initial Public Instruction was already planted (Fernandes Pinheiro, J. C. (1872). Literature, Public Instruction in Brazil II (Transcription). Jornal do Aracaju, 3, n 273, p. $4)$.

Rizzini and da Silva Araújo (2011) identified the national and international movement aiming at spreading elementary education in Brazil. For the authors, the second half of the nineteenth century was a period in which the number of schools and enrolled students represented progress and the degree of civilization of a nation. Furthermore, theater, dances and banquets, the square and the market were elected symbols to demonstrate this new moment in society. This change in behavior was encouraged by the expansion of education and refinement of taste showed signs of social differentiation, in this context, the newspapers fulfilled the function of disseminating these new patterns of behavior.

The power of the printed word influenced public opinion, customs and changed opinions not only intellectual, but also those who were not named so through collective reading aloud. It was believed that society could be improved through the circulation of ideas, heritage of the Enlightenment. Thus, the press in the nineteenth century was set as a strategy in building society, having an educative role (Inácio, 2009).

Accordingly, the President of the province of Sergipe, Joaquim Bento de Oliveira Junior (07/16/1872-11/05/1872), published a text, and, in the introduction, it was stated that the people of Sergipe would not fail to assist the president of the province in his efforts to develop Public Instruction. For the President "instruction is now the magic word of the century, and the basis on which all the countries intend to establish their prominence. It is fair, therefore, that the province of Sergipe do not be left behind of such a noble movement" (Luiz, M. (1872). Public Instruction. Jornal do Aracaju, 3, n 301, p. 2).

\section{Conclusions}

After these considerations on Public Instruction, it may be inferred that the nations and centers of modern knowledge were the mirrors through which the nineteenth-century Brazil sought to forge their own image. Hegemonic designs of those nations have influenced the behavior of people and their family habits (do Nascimento, 1999).

In this sense, we can consider the design of Elias (1990) in which the civilizing process is seen as a slow construction work of man by man. Thus, the events, however, 
absurd or unimportant they may seem, when taken in isolation, change their degree of significance once articulated to others who make up this process and that are configured in long-term changes in the structures of control of people in the societies in which they live.

After these considerations about the organization of Public Instruction in Switzerland, the United States, Brazil and France, it is possible to state that the institution of elementary education was a process that owned reference in Western nations, respecting the particularities of each of them, in a diverse cultural historical setting.

The mentioning of other countries was a strategy commonly used in Brazil and other Latin American countries under a pedagogical and convincing tool by claiming to " $[. .$. demonstrate meaning towards civilizing process lived by human societies" (de Faria Filho \& de Sales, 2009: p. 30). To this end, the press was used by intellectuals as dissemination of their legalistic and civilizational discourse strategy.

As a central element in the movement to institutionalize school under the aegis of the state, mandatory education arises as a model of governance when it comes to Public Education. For that matter it aimed at being innovative, therefore, a network of political-administrative and cultural practices was needed at that time (Gondra \& Shueler, 2008).

Obviously, the fact that those nations were considered "advanced" provided the possibility of their "educational policies" should be taken as a reference, leading to comparisons and subsequent adaptations.

There was an intention to show the school as a place of excellence in broadcast, homogenization of knowledge and inculcation of behaviors. To anchor this idea, the State had to create mechanisms that made its agents interact in circularity of actions among themselves and with parents and their children. One example of this mechanism was when the State created a legislation that also needed inspection agents to effectively be put into practice, it also needed the "arm" of justice to force families to send their children to school.

All those considerations show the fertile period that the nineteenth century was when a debated about education was promoted, producing a plurality of initiatives, having educational practices shared as well as creating a school form that was implemented throughout that period. They have shown that the agents of that process promoted remodeling of space, time and educational knowledge, leaving a legacy that cannot be denied.

\section{Acknowledgements}

We thank Tiradentes University for its support and sponsorship.

\section{References}

Cardoso, B. (1872). Warning. Jornal do Aracaju, 3, n 248, p. 1.

Cury, C. E. (2011). Educacional Culture in Texts for Newspapers in the 19th Parahyba. In C. A. Castro, \& C. E. Cury (Orgs.), Objets, Practices and School Individuals in the North and in the 
Northeast (pp. 35-46). São Luís: EDUFMA: UFPB: Café \& Lápis.

Darnton, R. (2010). The Case for Books: Past, Present, and Future. São Paulo: Companhia das Letras.

de Carvalho Borges, A. P. (1872). Ministry of Foreign Affairs (Transcription). Jornal do Aracaju, $3, \mathrm{n}^{\circ} 279$, p. 4

de Faria Filho, L. M. (1998) School Legislation as Source for History of Education: An Interpretation Attempt. In: D. G. Vidal et al. (Orgs.), Education, Modernity and Civilization (pp. 89-125). Belo Horizonte: Autêntica.

de Faria Filho, L. M., \& de Sales, Z. E. S. (2009). Brazilian Childhood Schooling: The Contribution of Bachelor Bernardo Pereira de Vasconcelos. In: L. M. de Faria Filho, \& M. D. Inácio (Orgs.), Politicians, Writers, Teachers, Intellectuals: The Public Debate about Education in Minas Gerais (pp. 21-44). Belo Horizonte: Mazza Edições.

de Luca, T. R. (2006). Printed Sources: History of, in and through Newspapers. In: C. B. Pinsky (Org.), Historical Sources (pp. 111-153). São Paulo: Contexto.

do Nascimento, J. C. (1999). The Hidden Culture or the German Influence in the Brazilian Culture during the Second Half of the 19th Century. Londrina: Editora UEL.

Elias, N. (1990). The Civilizing Process: The History of Manners. Rio de Janeiro: Jorge Zahar.

Essen, M., \& Rogers, R. (2003) Écrire l'histoire dês enseignantes. Enjeux et perspectives internationales. Histoire de L'Education: lês enseignantes $X I X-X X$ siècles, Lyon, No. 98, 5-36.

Fernandes Pinheiro, J. C. (1872). Literature, Publicinstruction in Brazil II (Transcription). Jornal do Aracaju, 3, n²73, p. 4.

Gondra, J. G., \& Schueler, A. (2008). Education, Power and Society in the Brazilian Empire. São Paulo: Cortez.

Inácio, M. S. (2009) Scholars, State and Education in 1831-1840. In L. M. Faria Filho, \& M. S. Inácio (Orgs), Politicians, Writers, Teachers, Scholars: The Public Debate about Education in Minas Gerais (pp. 45-66). Belo Horizonte: Mazza Editions.

Luiz, M. (1872). Publicinstruction. Jornal do Aracaju, 3, n 301, p. 2.

Miranda, I. V. (2009). Knowledge and Fear: Disciplinary and Punishing Methods in Education in Parahyba do Norte Province from 1822 to 1864. 2009. 65f. Monography (Department of History, at Center of Human Letters and Arts), Federal University of Paraiba.

No Authorship (1872a). Publicinstruction. Jornal do Aracaju, 3, n² 247, p. 1.

No Authorship (1872b). Education Publishes-Memory on This Matter, Presented by the Brazilian Minister in Switzerland (Transcription). Jornal do Aracaju, 3, n 287, 2-3.

No Authorship (1872c). A Public Instruction in France-Primary Instruction (Transcription). Jornal do Aracaju, 3, n 294, p. 3.

No Authorship (1872d). Public Instruction in France-OVERVIEW-Primary Instruction I-Continued from $\mathrm{n}^{\circ} 296$ (Transcription). Jornal do Aracaju, 3, n² 297, 2-3.

No Authorship (1872e). Public Instruction in France-OVERVIEW-Primary Instruction I (Transcription Continued from Issue 299). Jornal do Aracaju, 3, n 300, p. 2.

Provincial Government (1872a). Government of the Province: March 9, 1872. Jornal do Aracaju, $3, \mathrm{n}^{\circ} 249$, p. 1.

Provincial Government (1872b). Government Expedient. Jornal do Aracaju, 3, n 260, p. 1.

Provincial Government (1872c). Provincial Assembly: Session on April 12, 1872-Part 2 of the Agenda. Jornal do Aracaju, 3, n² 266, p. 1.

Provincial Government (1872d). Government Expedient: 1st Part of the Agenda. Jornal do Ara- 
caju, $3, \mathrm{n}^{\circ} 267$, p. 3

Provincial Government (1872e). Provincial Assembly: Session on May 2, 1872. Jornal do Aracaju, $3, n^{\circ} 275$, p. 2.

Provincial Government (1872f). Law 951 of May 8, 1872. Jornal do Aracaju, 3, n² 284, p. 1.

Ribeiro, O. (1872). Provincial Assembly: Speech Delivered by Mr. Oliveira Ribeiro in Session 11 of the Ongoing Year. Jornal do Aracaju, 3, n 263, p. 1.

Rizzini, I., \& da Silva Araújo, S. M. (2011). Education and Instruction in Amazon and Para Provinces. In: J. G., Gondra, \& O. Schneider (Orgs.), Education and Instruction in the Provinces in the Imperial Court (Brazil, 1822-1889) (pp. 15-48). Vitória: EDUFES.

\section{Submit or recommend next manuscript to SCIRP and we will provide best service} for you:

Accepting pre-submission inquiries through Email, Facebook, LinkedIn, Twitter, etc.

A wide selection of journals (inclusive of 9 subjects, more than 200 journals)

Providing 24-hour high-quality service

User-friendly online submission system

Fair and swift peer-review system

Efficient typesetting and proofreading procedure

Display of the result of downloads and visits, as well as the number of cited articles

Maximum dissemination of your research work

Submit your manuscript at: http://papersubmission.scirp.org/

Or contact ce@scirp.org 